\title{
Transitional carcinoma with extensive invasion of the bony orbit in a dog
}

\author{
[Carcinoma transicional com invasão dos ossos da órbita em um cão] \\ S.C.C.S. Paiva ${ }^{1}$, J. Werner ${ }^{1}$, F. Montiani-Ferreira ${ }^{2 *}$, T.R. Froes ${ }^{2}$, M. Machado ${ }^{3}$, \\ L. Olbertz ${ }^{2}$, L. Lima ${ }^{2}$, I. Langohr ${ }^{4}$ \\ ${ }^{1}$ Aluna de pós-graduação - Universidade Federal do Paraná - Curitiba, PR \\ ${ }^{2}$ Universidade Federal do Paraná - Curitiba, PR \\ ${ }^{3}$ Universidade do Contestado - Canoinhas, SC \\ ${ }^{4}$ Michigan State University - Michigan, USA
}

\begin{abstract}
A 12-year-old male English Pointer was examined due to a soft-tissue swelling at the medial canthus of the right orbital region, which was causing facial deformity. The dog had epiphora, purulent nasal discharge, epistaxis, dyspnea, and progressive weight loss. An intraoral mass was observed near the right maxillary premolars. Neoplastic disease was diagnosed based on ancillary tests, which included blood work, skull and intraoral radiographs, ocular ultrasonography and computed tomography. Histopathology revealed transitional carcinoma involving the nasal and oral cavities, maxilla, bony orbit and retrobulbar space. Nasal tumors represent approximately $2 \%$ of all tumors diagnosed in this species. Transitional carcinoma is the second most common type of malignant epithelial tumor in the nasal sinuses. This case illustrates the extensive destruction of the soft and bony tissues of the face, including the bony orbit that this type of tumor can cause.
\end{abstract}

Keywords: respiratory neoplasm; orbital neoplasm; retrobulbar mass; computed tomography

\section{RESUMO}

Um cão da raça Pointer Inglês, de 12 anos de idade, foi encaminhado para avaliação clínica por apresentar aumento de volume no canto temporal (medial) da órbita direita, o qual estava causando deformidade facial. $O$ cão apresentava epífora, secreção nasal mucopurulenta, epistaxe, dispnésia e perda de peso progressiva. Uma massa foi observada na cavidade oral, próxima aos dentes pré-molares, do lado direito da face. Suspeitou-se de proliferação neoplásica baseando-se nos testes auxiliares, entre os quais: radiografia craniana e oral, ultrassonografia ocular e tomografia computadorizada. A análise histopatológica da massa revelou tratar-se de carcinoma transicional envolvendo as cavidades oral e nasal, os ossos da maxila e da órbita, além do espaço retrobulbar. Os tumores da cavidade nasal representam aproximadamente $2 \%$ de todos os tumores diagnosticados nessa espécie. O carcinoma transicional é o segundo tipo de neoplasia epitelial maligna mais comum nos seios nasais de cães. Este trabalho descreve a destruição extensiva dos tecidos moles e dos ossos da face e chama atenção para o fato de que esse tipo de neoplasia deve ser considerado nas doenças da órbita.

Palavras-chave: neoplasia do trato respiratório, neoplasia da órbita, massa retrobulbar, tomografia computadorizada

Recebido em 13 de novembro de 2011

Aceito em 29 de novembro de 2012

*Autor para correspondência (corresponding author)

e-mail: montiani@ufpr.br 


\section{INTRODUCTION}

Nasal tumors are infrequently reported in small domestic animals (Wilson and Dungeword, 2002; Correa et al., 2003; Lopez, 2007) and represent approximately $2 \%$ of all tumors in $\operatorname{dogs}$ and $1 \%$ in cats. About $80 \%$ of all nasal tumors in dogs are malignant, with $60-75 \%$ of malignant intranasal tumors being of epithelial origin (Legendre, 1983; Mukaratirwa et al., 2001; Morrison, 2002; Wilson and Dungeword, 2002). Even though distant metastasis of these tumors is rarely observed (Turek e Lana, 2007), the longterm prognosis for dogs and cats with nasal carcinoma is poor because the disease is usually diagnosed in an advanced stage in a critical location near the eyes and brain. Survival time depends in part on the immune defenses of the host (Mukaratirwa et al., 2001). The sinonasal carcinomas usually originate in the nasal vestibule and sinuses and may invade neighboring tissues (Katz et al., 2002). Due to the proximity to the base of the skull, the brain and the bony orbit, these carcinomas represent a therapeutic challenge (Katz et al., 2002; Khademi et al., 2009).

This case report describes clinical and pathologic findings in a dog with nasal transitional carcinoma extensively invading the bony orbit, retrobulbar space, maxilla and oral cavity. Due to extensive tissue destruction that this type of tumor can cause, it should be included in the list of possible neoplastic disease affecting the retrobulbar space and bony orbit in this species.

\section{CASE DESCRIPTION}

A 12-year-old male English Pointer was referred to the Ophthalmology Service of the Federal University of Paraná, Curitiba-PR, Brazil, for clinical evaluation. The chief complaint was epiphora and a two-month history of progressive swelling involving the right medial orbital region and extending cranially up the snout (Figure 1, A, B and C). The dog also had inspiratory stridor, epistaxis and some degree of masticatory difficulty. The parotid and mandibular lymph nodes on the right side were enlarged. There was an intraoral soft tissue mass near the right maxillary premolar. The right eye appeared slightly exophthalmic. The dog was visual under scotopic and photopic conditions, had intact menace responses and had normal direct and indirect pupillary light reflexes in both eyes (OU). Schirmer tear test values were also normal (15 mm OS and $16 \mathrm{~mm} \mathrm{OD),} \mathrm{as} \mathrm{was} \mathrm{intraocular}$ pressure (12 mmHg OD and $10 \mathrm{mmHg}$ OS), which was measured using an applanation tonometer (Tonopen XL, Mentor Ophthalmics, Norwell, MA, USA). The right globe could not be retropulsed. No ocular lesions were seen under slit-lamp biomicroscopic and indirect ophthalmoscopic examinations after pupillary dilatation using $1 \%$ tropicamide. No restriction to ocular motility was noted when moving the eye with forceps, suggesting that the extra-ocular muscles were not entrapped. Complete blood count revealed anemia (hematocrit of $20 \%$, normal range $37-55 \%$ ) and a chemical serum evaluation showed a moderate increase in alkaline phosphatase (215IU/L, normal range 44 - 147IU/L - colorimetric total alkaline phosphatase assay). No other alterations on WBC count or morphology were observed.

Due to grave prognosis, the owners decided to euthanize the dog. Samples of the neoplastic tissue located in the right retrobulbar space were collected. Lymph nodes were not collected. No other significant changes were observed during necropsy.

The patient was anesthetized for proper physical examination of the oral mass and received premedication with midazolam $0.4 \mathrm{mg} / \mathrm{kg}$ (Dormire ®; Cristália Brazil) and pethidine 3mg/kg (Dolosal ®; Cristália Brazil) intramuscularly. Anesthesia was induced with propofol infusion $6 \mathrm{mg} / \mathrm{kg}$ (Propovan ${ }^{\circledR}$; Cristália Brazil) intravenously and was maintained with isoflurane (Foran $®$, Abbott, Buenos Aires, Argentina) via endotracheal intubation. Intraoral radiography was performed, a sample of the mass was collected for cytology and histopathology, and the right upper premolars affected by the mass were extracted.

B-mode scan ultrasonography of the right eye was performed using a Sonix SP High Performance B-mode System (Ultrasonix, Richomond, BC, Canada). The B-scan 14-MHz probe was gently placed on the corneal surface perpendicular to the center of the cornea using ultrasonic transmission gel (Aquasonic-100; Parker Laboratories Inc., Fairfield, NJ, USA). A hypoechoic area was noted in the retrobulbar space, but no globe indentation was present. 
Radiography of the skull revealed opacification of the right nasal cavity, swelling of soft tissues, destruction of the hard palate, opacification of the ethmoturbinates and the cribriform plate of the ethmoid bone, and irregularity and osteolysis of the alveolar bone.

Computed tomography (CT) (Multidetector Toshiba Super Four Einstein, Toshiba America Medical System, Inc.,Tustin, CA) ( Figure 2 A) examination of the dog's right orbital region on positive contrast images revealed a mass invading adjacent areas of facial and cranial bones. The maxillary bone was widely affected and damage involved its orbital, facial, nasal and pterygopalatine surfaces resulting in significant bone loss of the hard palate, overlying vomer, and right lateral wall of the nasal cavity with some extension into its nasal roof and left wall. Additional loss of the right maxillary bone had occurred at the level of the infraorbital foramen and canal, alveolar canal and margin from the canine to the fourth premolar tooth, maxillary recess, and lacrimal canal and sulcus. Other regions affected were the horizontal plate of the palatine bone, nasal bones, frontal bone, including the rostral, lateral, and medial sinuses and orbital surface, ventral and dorsal nasal conchae, lacrimal bone including the facial and nasal surfaces, zygomatic bone at its articulation with the maxillary bone, and incisive bone. The whole retrobulbar space on the right side of the face was filled with the mass, and tissue invasion was present also in the pterygopalatine fossa, nasopharynx and oral cavity.

Bone destruction was further observed in the pterygoid bone, perpendicular plate of the palatine bone, body of the basisphenoid bone and sphenoid sinus, and wing of the presphenoid bone (Figure 1, B and D). The mass was present along the whole length of the right half of the nasal cavity extending into the frontal sinuses.

Histopathology of tissue samples (both biopsied and collected during necropsy from the retrobulbar space) revealed a fairly well delimited, non-encapsulated neoplasm extensively expanding the submucosa of the nasal cavity. The neoplasm was composed of coalescing solid nests and broad trabeculae of polygonal neoplastic and palisading tall columnar epithelial cells separated by delicate fibrovascular septa (Figure 3A). The neoplastic cells had indistinct borders, scant to moderate pale eosinophilic cytoplasm, and round or ovoid nuclei with coarsely stippled chromatin and occasional single distinct nucleolus. Single cell necrosis was common. Nuclear atypia was mild. There was an average 10 mitoses per high power $(400 x)$ field. Blood vessels surrounding the tumor were often cuffed by moderate numbers of lymphocytes. Rare lymphatics at the tumor margins contained aggregates of neoplastic cells (Figure 3). Findings were consistent with transitional carcinoma.

\section{DISCUSSION}

Transitional carcinoma of the respiratory epithelium is infrequently reported in dogs (Patnaik, 1989; Wilson and Dungeword, 2002; Lopez, 2007). The term transitional carcinoma is recommended by the World Health Organization for this kind of tumor in dogs (Dungworth et al., 1999), despite sometimes being reported as respiratory epithelial carcinoma, non-keratinizing squamous cell tumor or undifferentiated carcinoma (Dungworth et al., 1999; Wilson and Dungword, 2002; Caswell and Williams, 2007).

Transitional carcinomas are locally invasive and represent a therapeutic challenge to the veterinary surgeon (O'Brien et al., 1996). Among the sinonasal region tumors, adenocarcinoma is the most common in dogs, followed by transitional carcinoma and then squamous cell carcinoma (Sako et al., 2005; Ninomya et al., 2008). The tumors of the nasal cavity have only moderate metastatic potential in dogs (Malinowski, 2006; Silva et al., 2009). The lethality and poor prognosis of these malignant tumors are directly related to the late or misleading clinical signs, which allow extensive tumor growth before discovery. 

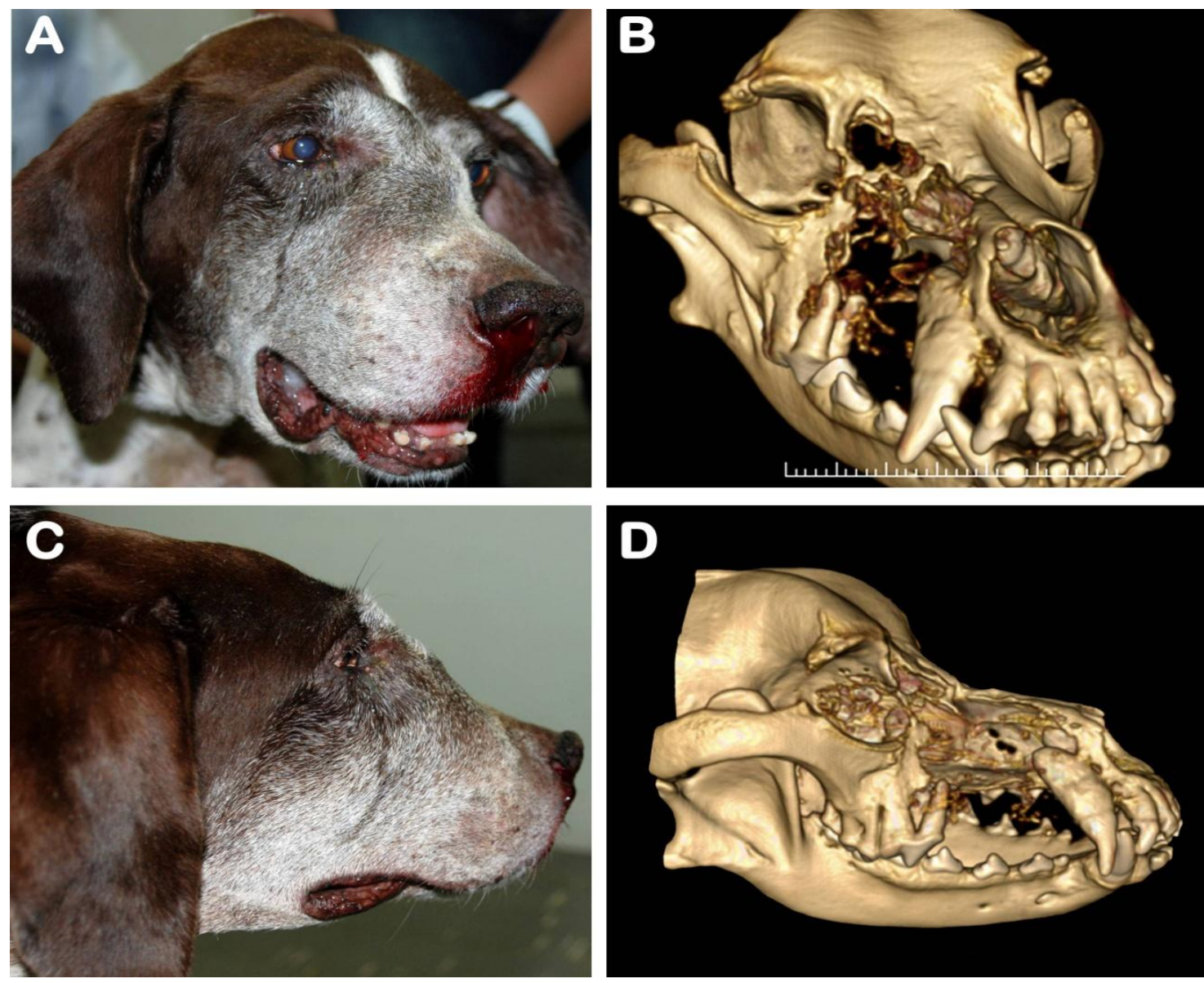

Figure 1. Dog. Clinical photographs (A and C) demonstrating epiphora, epistaxis and facial deformity due to soft-tissue swelling located medially around the right orbital region. Three-dimensional volume rendering of the skull using the workstation of the computed tomography equipment ( $\mathrm{B}$ and $\mathrm{D})$ revealed extensive bone loss due to neoplastic involvement of the right bony orbit, oral and nasal cavities, hard palate, vomer bone, maxillary bone, ethmoid bone, ethmoturbinate, and frontal bone.
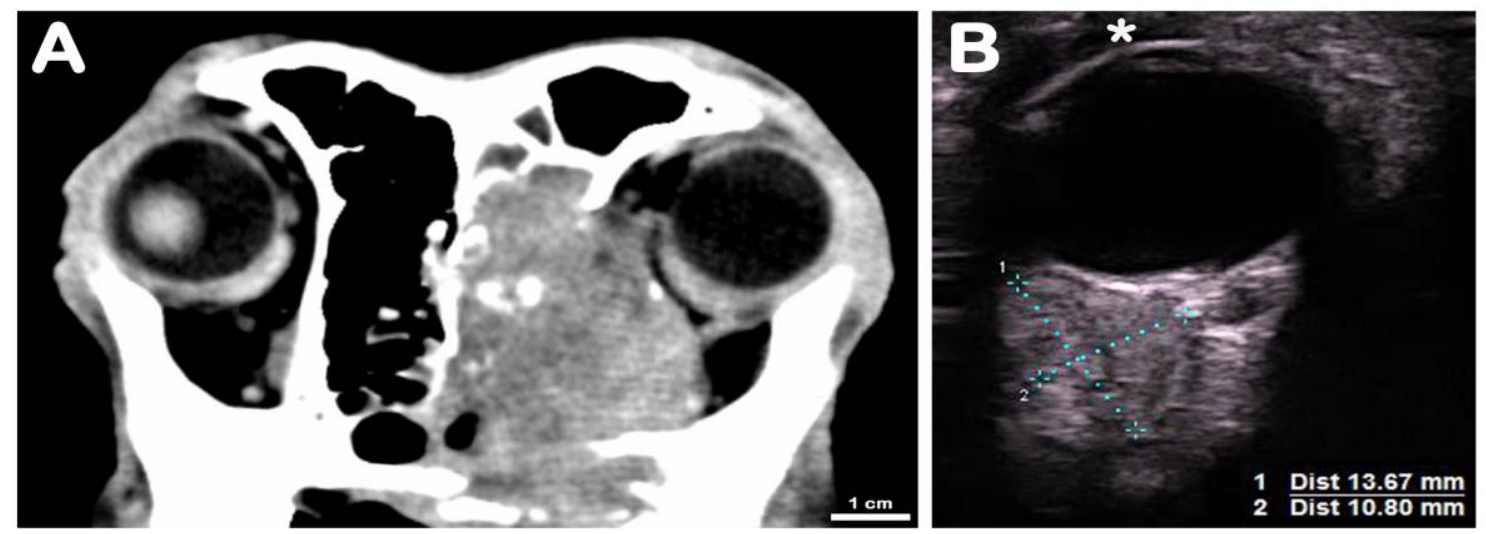

Figure 2. Dog. (A) Axial computed tomography scan image showing the extensive tumor involvement of the frontal sinuses, bony orbit, orbital cavity, pterygopalatine fossa, nasopharynx, and oral cavity on the right side. B) Ultrasonogram demonstrating a soft tissue mass measuring 13.67 x 10.80mm (dotted lines 1 and 2) in the right retrobulbar space. Asterisk indicates corneal surface. 

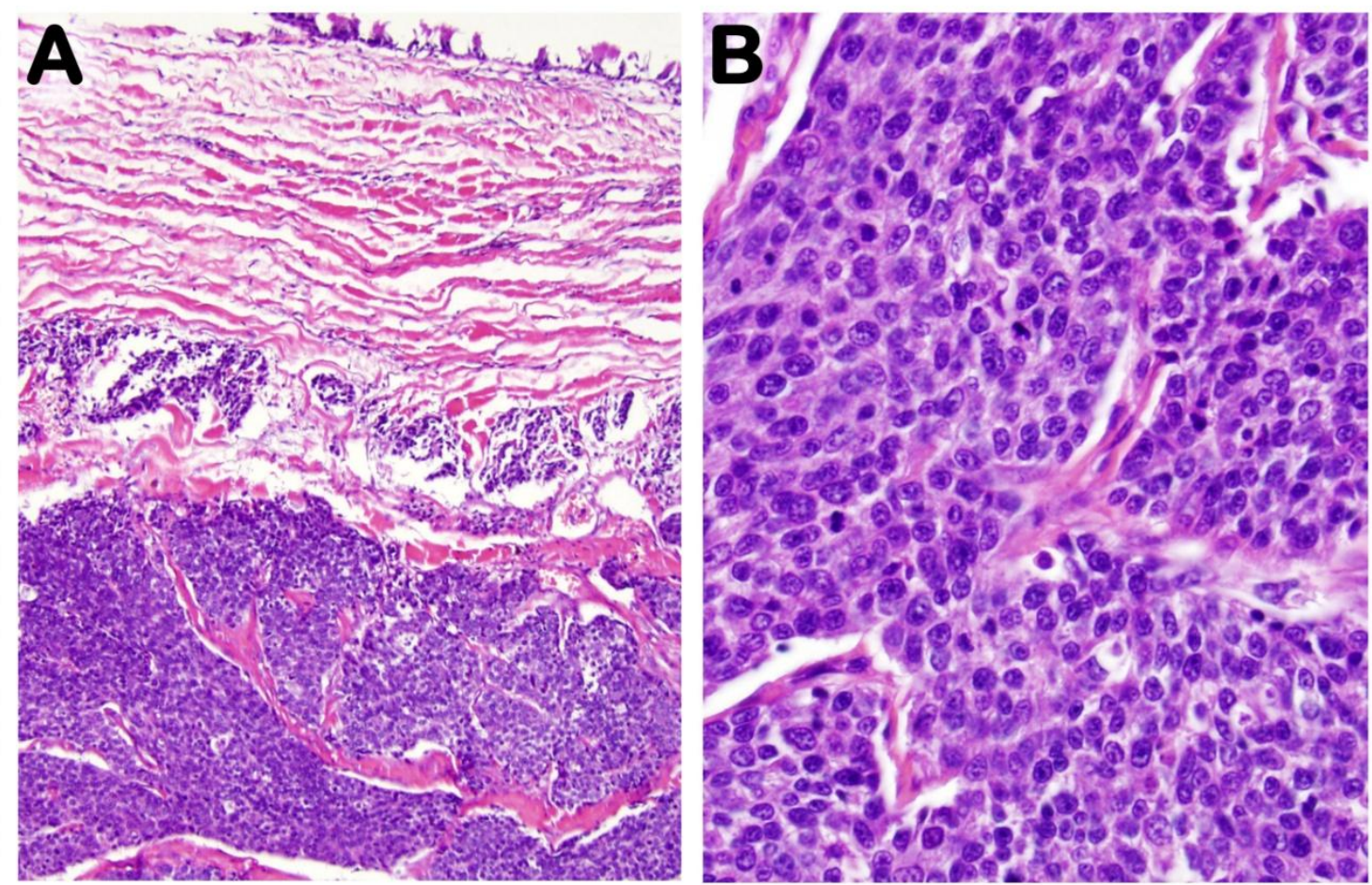

Figure 3. Dog. Photomicographs of the retrobulbar tissue mass. A) Fairly well delimited, nonencapsulated neoplasm seen here in the deep nasal submucosa (H\&E 200x). B) The neoplasm is composed of coalescing solid nests and broad trabeculae of polygonal neoplastic epithelial cells separated by delicate fibrovascular septae characteristic of transitional carcinomas (H\&E 400x).

In human beings, various factors have been implicated in the etiology of nose and paranasal sinus neoplasms. Inflammations such as chronic sinusitis and nasal polyps have been suggested as possible etiologic factors of nasosinus tumors. Occupational exposure in the lumber industry, nickel refineries, boot and shoe making, urban pollution as well as the textile industry, increases cell proliferation and have, therefore, been suggested as additional causative factors for malignant transformation. In several studies a substantial number of patients were addicted to alcohol and smoking (Monticello et al., 1993; Calderón-Garcidienas et al., 1999; Dubey et al., 1999; Choong and Vokes, 2008). It is known that the metabolism of xenobiotics into reactive intermediate molecules may play a role in neoplastic transformation (Caswell and Williams, 2007). The metabolism of inhaled xenobiotics in the canine nose is endowed with a complement of cytochrome P450 monooxygenase enzymes within the smooth endoplasmic reticulum. It was noted that this dog lived near a sawmill (about 100 meters).
However, no cause-effect relationship in this case could be established.

In dogs, the most commonly reported clinical signs associated with orbital neoplasia include slowly progressive exophthalmos, strabismus, protrusion of the third eyelid, resistance to retropulsion, periocular swelling, absence of pain, exposure keratitis and sometimes blindness (Hendrix and Gelatt, 2000). In the present case, the tumor invasion of the orbit as seen on CT and ultrasonography was responsible for the slight exophthalmia observed clinically. Epiphora was also related to tumor invasion of the lacrimal apparatus as well as obvious bony loss of the lacrimal canal and sulcus. Although elevated alkaline phosphatase is a nonspecific finding, in this case it can be associated with bone tissue destruction. In terms of spreading capacity, few tumors behave like transitional carcinomas. In a retrospective study of 44 cases of orbital neoplasia in dogs, most tumors were considered to arise from the orbit, with relatively fewer 
invading the orbit from adjacent structures (Hendrix and Gelatt, 2000).

Periorbital tumors present a therapeutic challenge to the veterinary surgeon. It is often necessary to perform regional radiography, CT scans and ultrasonography to properly investigate possible invasion into the nasal cavity, paranasal sinuses, retrobulbar space and oral cavity (Font and Ferry, 1976; Hendrix and Gelatt, 2000; Turek and Lana, 2007). A CT scan is an excellent method to demonstrate mass effect, opacification and bone destruction (Le Blanc and Daniel, 2007).

The diagnosis of the type of orbital disease still depends on histopathologic examination after tissue sample collection (Park et al., 1992; Lefebre et al., 2005). Nasal CT greatly enhances the clinician's ability to diagnose and stage intranasal neoplasia. A CT can identify optimal areas for rhinoscopy and biopsy to confirm the cause of the disease process in question. For dogs with intranasal neoplasia, CT provides an accurate assessment of tumor size, extent of disease within and outside the nasal cavity, and presence of bone destruction (Jonhson and Wisner, 2007). Because a thorough necropsy and relevant tissue collection were not performed in this case, the possibility of metastatic disease could not be totally excluded.

Even though no treatment protocol was attempted since the dog was euthanized, it is worth mentioning that the treatment of nasal transitional carcinoma is a challenge and has been studied for years. Currently it seems that neither chemotherapy nor surgical procedure have significant influence on the mean survival time for patients with transitional carcinoma (Wilson and Dungword, 2002). Survival time after surgery alone is similar to the survival time with no treatment at all. Similarly, surgical intervention before radiotherapy has not proved to improve the clinical outcome (Turek and Lana, 2007).

Radiation therapy can induce complications to the normal tissue surrounding the tumor, such as the oral cavity, nasal cavity, skin and the eyes (Ogilvie and LaRue, 1992; Turek and Lana, 2007). A study done with intensity-modulated radiation therapy showed lesser degree of radiation toxicity in the eye closer to the neoplastic lesion and total contralateral ocular sparing in dogs with sinonasal tumors treated with this technique (Hunley et al., 2010). Helical tomotherapy is a novel form of radiation that uses image verification, an intensity-modulated, fan-shaped radiation beam that rotates around the patient, allowing a conformal radiation precisely to the desired target. Its results have proved to increase survival times in dogs, efficiently sparing surrounding tissues and reducing side effects (Turek and Lana, 2007; Hunley et al., 2010; Lawrence et al., 2010).

This case illustrates the extensive destruction that a transitional carcinoma can cause on soft facial tissue and bony tissues including the bone orbit. We believe this report will add to clinical information about transitional carcinoma and discuss possible differential diagnoses for progressive periocular swelling of the bony orbit in dogs.

\section{REFERENCES}

CALDERÓN-GARCIDIENAS, L.; RODRIGUEZALCARAZ, A.; GARCIA, R. et al. Cell proliferation in nasal epithelium of people exposed to urban pollution. Carciogenesis, v.20, p.383-389, 1999.

CASWELL, J.L.; WILLIAMS, K.J. Respiratory system. In: Maxie M.G. (Ed). Jubb, Kennedy and Palmer's Pathology of Domestic Animals. 5.ed. London: Elsevier Saunders, 2007. p.535-536.

CHOONG, N.; VOKES, E. Expanding role of the medical oncologist in the manangement of head and neck cancer. Cancer J. for Clin., v.58, p.32-53, 2008.

CORREA, S.S.; MAULDIN, G.N.; MAULDIN, G.E. et al. Efficacy of cobalt-60 radiation therapy for the treatment of nasal cavity nonkeratinizing squamous cell carcinoma in the dog. J. Am. Anim. Hosp. Assoc., v.39, p.86-89, 2003.

DUBEY, S.P.; MURTHY, D.P.; KALEH, L.K. et al. Malignant tumors of the nasal cavity and the paranasal sinuses in a Melanesian population. Auris Nasus Larynx, v.26, p.57-64, 1999.

DUNGWORTH, D.L.; HAUSER, B.; HAHN, F.F. et al. Histological Classification of Tumors of the Respiratory System of Domestic Animals. In: The WHO International Histological Classification of Tumors of Domestic Animals. The Armed Forces Institute of Pathology, Washington, 1999. v.VI. p.1718. 
FONT, R.L.; FERRY, A.P. Carcinoma metastatic to the eye and orbit- a clinicopathologic study of 28 cases metastatic to the orbit. Cancer, v.38, p.1326-1335, 1976.

HENDRIX, D.V.H.; GELATT, K.N. Diagnosis, treatment and outcome of orbital neoplasia in dogs: a retrospective study of 44 cases. J. Small Anim. Pract., v.41, p.105-108, 2000.

HUNLEY, D.W.; NEAL MAULDIN, G.; SHIOMITSU, K. et al. Clinical outcome in dogs with nasal tumors treated with intensity-modulated radiation therapy. Can. Vet. J., v.51, p.293-300, 2010.

JONHSON, E.G.; WISNER , E.R. Advances in respiratory imaging. J. Am. Vet. Med. Ass., v.37. p.879-900, 2007.

KATZ, T.S.; MENDENHALL, W.M.; MORRIS, C.G. et al. Malignant tumors of the nasal cavity and paranasal sinuses. Head Neck, v.24, p.821-829, 2002.

KHADEMI, B.; MORADI, A.; HOSEINI, S. et al. Malignant neoplasms of the sinonasal tract: report of 71 patients and literature review and analysis. J. Oral Maxillofac. Surg., v.13, p.191-199, 2009.

LAWRENCE, J.A.; FORREST, L.J.; TUREK, M.M. et al. Proof of principle of ocular sparing in dogs with sinonasal tumors treated with intensity-modulated radiation therapy. Vet. Radiol. Ultrasound, v.51, p.561-570, 2010.

LeBLANC, A.K.; DANIEL, G.B. Advanced imaging for veterinary cancer patients. Vet. Clin. North Am. Small Anim. Pract., v.37, p.1059-1077, 2007.

LEFEBRE, J.; KUEN, N.F.; WORTINGER, A. Computed tomography as an aid in the diagnosis of chronic nasal disease in dogs. J. Small Anim. Pract., v.46, p.280-285, 2005.

LEGENDRE, A.M. Canine nasal and paranasal sinus tumors. J. Am. Anim. Hosp. Assoc., v.19, p.115-123, 1983.

LÓPEZ, A. Respiratory system. In: McGAVIN, M.D.; ZACHARY, J.F. (Eds). Pathol. Basis of Vet. Disease. 4.ed. Saint Louis: Mosby Elsevier, 2007. p.484-486.

MALINOWSKI, C. Canine and feline nasal neoplasia. Clin. Tech. Small Anim. Pract., v.21, p.89-94, 2006.

MONTICELLO, T.M.; GROSS, E.A.; MORGAN, K.T. Cell proliferation and nasal carcinogenesis. Environ. Health Perspect., v.101, p.121-124, 1993.
MORRISON, W.B. Cancer in dogs and cats. In: JACKSON, W.Y. (Ed). Med. Surgic. Managem., 2. ed. Philadelphia: Lippincott, 2002. p.497-512.

MUKARATIRWA, S.; VAN DER LINDE-SIPMAN, J.S.; GRUYS, E. Feline nasal and paranasal sinus tumors: clinicopathological study, histomorphological description and diagnostic immunohistochemistry of 123 cases. J. Feline Med Surg., v.3, p.235-245, 2001.

NINOMYA, F.; SUZUKI, S.; TANAKA, H. et al. Nasal and paranasal adenocarcinomas with neuroendocrine differentiation in dogs. Vet. Pathol., v.45, p.181-187, 2008.

O'BRIEN, M.G.; WITHROW, S.J.; STRAW, R.C. et al. Total and partial orbiectomy for the treatment of periorbital tumors in 24 dogs and 6 cats: a retrospective study. Vet. Surg., v.25, p.471-479, 1996.

OGILVIE, G.K.; LARUE, S.M. Canine and feline nasal and paranasal sinus tumors. Vet. Clin. North Am. Small Anim. Pract., v.22, p.1133-1144, 1992.

PARK, R.D.; BECK, E.R.; LECOUTEUR, R.A. Comparison of computed tomography and radiography for detecting changes induced by malignant nasal neoplasia in dogs. J. Am. Anim. Hosp. Assoc., v.201, p.1720-1724, 1992.

PATNAIK, A.K. Canine sinonasal neoplasms: clinicopathologic study of 285 cases. Am. Anim. Hosp. Assoc., v.25, p.103-114, 1989.

SAKO, T.; SHIMOYAMA, Y.; AKIHARA, Y. et al. Neuroendocrine carcinoma in the nasal cavity of ten dogs. J. Comp. Pathol., v.133, p.155-163, 2005.

SILVA, M.C.V.; DE NARDI, A.B.; RODASKI, S. Neoplasias do sistema respiratório. In: DALECK, C.R.; DE NARDI, A.B.; RODASKI S. (Eds). Oncologia em Cães e Gatos. 1. ed. São Paulo: Rocca, 2009. p.336-343.

TUREK M.M.; LANA, S.E. Canine nasosinal tumors. In: WITHROW, S.J.; VAIL, D.M. (Eds). Withrow and MacEwen's Small Animal Clinical Oncology. 4. ed. Saint Louis: Saunders, 2007. p.525-535.

WILSON, D.W.; DUNGWORD, D.L. Tumors of the respiratory tract. In: MEUTEN, D.J. (Ed). Tumors of Domestic Animals. 4.ed. Iowa: Blackwell Publishing, 2002. p.365-399. 